\title{
ВЕСТНИК РГГУ
}

\author{
Научный журнал
}

Серия «Филология. Вопросы языкового родства» 
Российский государственный гуманитарный университет

Институт языкознания Российской Академии наук

\title{
Вопросы языкового родства
}

\author{
Международный научный журнал
}

№ 15, часть 3-4 (2017)

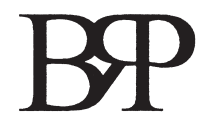

Москва 2017 
Russian State University for the Humanities

Institute of Linguistics of the Russian Academy of Sciences

\section{Journal of Language Relationship}

International Scientific Periodical

№15, issue 3-4 (2017)

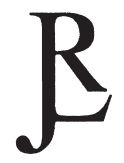

Moscow 2017 
Редакциионный совет:

Вяч. Вс. ИвАНОв (Москва- Лос-Анджелес) / председатель

Х. АЙХНЕР (ВеНа)

В. БЛАЖЕК (БРНО)

У. БЭКСТЕР (Анн Арбор)

В. Ф. ВЫдРИН (Париж)

М. ГЕЛл-МАНН (Санта-Фе)

Ф. КОРТлАНДТ (Дейден)

А. АуБОЦкиЙ (Дейден)

Дж. МэллОРИ (Белфаст)

А. Ю. МИЯИТАРЕВ (Москва)

П. ХАЙМАН (Беркли)

Редакциионная колиегия:

В. А. ДЫБО (главный редактор)

Г. С. СТАРОСТИН (заместитель главного редактора)

Т. А. МИХАЙЛОвА (ответственный секретарь)

А. В. ДЫБО

С. В. КУЛЛАНДА

М. А. МОАИНА

И. С. ЯКУБОВич

Журнал основан К. В. БАБАЕВЫМ 
Advisory Board:

Vyach. Vs. Ivanov (Moscow-Los Angeles, California) / Chairman

W. BAXTER (Ann Arbor, Michigan)

V. BLAŽEK (Brno)

H. EICHNER (Vienna)

M. Gell-Mann (Santa Fe, New Mexico)

L. HYMAN (Berkeley)

F. KORTLANDT (Leiden)

A. Lubotsky (Leiden)

J. P. MALLORY (Belfast)

A. Yu. Militarev (Moscow)

V. F. VYDRIN (Paris)

Editorial Staff:

V. A. DYвO (Editor-in-Chief)

G. S. STAROSTIN (Managing Editor)

T. A. Mikhailova (Editorial Secretary)

A. V. Dybo

S. V. KULLANDA

M. A. MOLINA

I. S. YAKUBOVICH

Founded by Kirill BABAEV

(c) Russian State University for the Humanities, 2017 
Вопросы языкового родства: Международный научный журнал / Рос. гос. гуманитар. ун-т; Рос. акад. наук. Ин-т языкознания; под ред. В. А. Дыбо. — М., 2017. — № 3-4(15). - xii + 166 с. - (Вестник РГГУ. Серия «Филология. Вопросы языкового родства»: Научный журнал).

Journal of Language Relationship: International Scientific Periodical / Russian State University for the Humanities; Russian Academy of Sciences. Institute of Linguistics; Ed. by V. A. Dybo. - Moscow, 2017. - No. 3-4(15). - xii + 166 p. - (RSUH/RGGU Bulletin. Series: Philology. Journal of Language Relationship: Academic Journal).

ISSN 2073-6320

http://www.jolr.ru/ gstarst@rinet.ru

Дополнительные знаки: С. Г. Болотов

Add-on symbols by S. G. Bolotov

Подписано в печать 20.12.2017. Формат 60×90/8.

Бум. офсетная.

Печать офсетная. Тираж 1050 экз.

Заказ №38

Издательский центр Российского государственного гуманитарного университета

125993, Москва, Миусская пл., 6 www.rggu.ru www.knigirggu.ru 